\title{
Peningkatan Akseptabilitas Susu Kecipir (Psophocarpus tetragonolobus (L.) DC.) dengan Adisi Bahan Penstabil dan Jus Jahe Increasing Acceptability of Winged-Bean (Psophocarpus tetragonolobus (L.) DC.) Milk by Addition of Stabilizer and Ginger Juice
}

Chiara Wijaya*, Leonardus Broto Sugeng Kardono, Jeremia Manuel Halim

Program Studi Teknologi Pangan Program Fakultas Sains dan Teknologi, Universitas Pelita Harapan, Tangerang Kementrian Riset dan Teknologi, Jakarta

*Korespondensi dengan penulis (chiarawijaya@yahoo.com)

Artikel ini dikirim pada tanggal 20 Maret 2015 dan dinyatakan diterima tanggal 09 April 2015. Artikel ini juga dipublikasi secara online melalui www.journal.ift.or.id. Hak cipta dilindungi undang-undang. Dilarang diperbanyak untuk tujuan komersial.

Diproduksi oleh Indonesian Food Technologists $®$ @2015 (www.ift.or.id)

\begin{abstract}
Abstrak
Rendahnya atensi masyarakat terhadap pemanfaatan kecipir (Psophocarpus tetragonolobus (L.) DC.) sebagai sumber protein alternatif disebabkan oleh rasa langu dari biji kecipir yang telah diproses. Penelitian ini bertujuan untuk meningkatkan akseptabilitas susu kecipir dengan penambahan bahan penstabil dan jus jahe. Metode blansir dengan air panas maupun uap secara signifikan tidak mempengaruhi penerimaan konsumen terhadap aroma, rasa, viskositas, dan akseptabilitas susu kecipir secara keseluruhan. Evaluasi terhadap efek berbagai rasio biji kecipir dengan air dan konsentrasi bahan penstabil pada stabilitas susu kecipir serta tingkat penerimaan konsumen menunjukkan bahwa susu yang dibuat dengan rasio 1:8 (biji kecipir:air) memiliki laju pengendapan terendah sebesar 0,0002 $\pm 0,0001 \mathrm{ppm} / \mathrm{m}$ dan sifat organoleptik yang lebih disukai konsumen. Hasil uji Consumer Rejection Threshold (CRT) untuk konsentrasi jus jahe gajah, jahe emprit, dan jahe merah yang ditambahkan ke dalam formulasi susu kecipir masing-masing adalah $26,91 \%, 12,27 \%$, dan 5,57\%. Tingkat akseptabilitas susu kecipir yang dibuat dengan rasio 1:8 (biji kecipir:air), 0,01\% kappa karagenan, dan $12,27 \%$ jus jahe emprit meningkat secara signifikan. Hasil uji fisikokimia menunjukkan bahwa susu kecipir yang dihasilkan memiliki nilai kecerahan warna 52,75, viskositas $16,18 \mathrm{mPa} . \mathrm{s}, \mathrm{pH} 6,92$, kandungan total fenol 0,27 mg EAG/g sampel, kandungan flavonoid 0,24 mg EK/g sampel, kapasitas antioksidan sebesar 14,53 mg EVC/L sampel $(26,62 \% \mathrm{SA})$, dan kandungan tanin sebesar $0,24 \mathrm{mg}$ EK/g sampel. Kandungan total padatan, protein, dan lemak dalam susu kecipir; yaitu masing-masing sebesar 10,29\%, 1,58\%, dan 0,88\% membuat produk ini memenuhi standar dan dapat disetarakan dengan produk minuman berbasis kedelai lainnya; namun kandungan nutrisinya masih lebih rendah daripada susu kedelai.
\end{abstract}

Kata kunci: rasa langu, CRT, jus jahe, kappa karagenan, susu kecipir.

\section{Abstract}

Little attention has been devoted to employ winged bean (Psophocarpus tetragonolobus (L.) DC.) as alternative source of dietary protein due to beany-flavour exposed from the processed beans. This research aimed to increase acceptability of winged-bean milk by addition of stabilizer and ginger juice. Both hot-water and steam blanching methods did not significantly affect consumer acceptability on aroma, flavour, viscosity, and overall acceptance. Evaluations for the effect of different winged beans to water ratios and stabilizer concentrations on milk stability and consumer acceptance showed that winged-bean milk with 1:8 (winged beans:water) ratio and 0,01\% kappa carrageenan had the lowest precipitation rate of $0,0002 \pm 0,0001 \mathrm{ppm} / \mathrm{m}$ and preferable organoleptic properties. Results of Consumer Rejection Threshold (CRT) for white, yellow, and red ginger juice concentration added into winged-bean milk were respectively $26,91 \%, 12,27 \%$, and $5,57 \%$. Formulation of $1: 8$ (winged beans:water) ratio, $0,01 \%$ kappa carrageenan, and $12,27 \%$ yellow ginger juice addition significantly increased acceptability of winged-bean milk. Physicochemical analysis results revealed that the resulted milk has 52,75 lightness value, viscosity of $16,18 \mathrm{mPa}$.s, $\mathrm{pH}$ of 6,92 , total phenolic content of $0,27 \mathrm{mg}$ gallic acid equivalent (GAE)/g sample, flavonoid content of $0.24 \mathrm{mg}$ quercetin equivalent (QE)/g sample, antioxidant capacity of $14,53 \mathrm{mg}$ vitamin C equivalent (VCE)/L sample $(26,62 \%$ scavenging activity), and tannin content of $0,24 \mathrm{mg}$ catechin equivalent (CE)/g sample. The content of 10,29\% total solid, $1,58 \%$ protein, and $0,88 \%$ fat made it qualified and comparable with other soy-based beverage products.

Keywords: beany odor, CRT, ginger juice, kappa carrageenan, winged-bean milk

\section{Pendahuluan}

Pemanfaatan tanaman kacang-kacangan dari family Leguminosae sebagai bahan pangan khususya sebagai sumber protein nabati semakin marak dikembangkan akhir-akhir ini. Dari 18.000 spesies legumes telah diidentifikasi, kacang kedelai; kacang tanah; kacang polong; dan lentil adalah beberapa jenis legumes yang paling banyak dibudidayakan (Salunkhe et al., 1992). Permintaan pasar terhadap makanan berbahan dasar kacang kedelai, khususnya di Indonesia 
telah mencapai 2,5 juta ton per tahun. Hal ini cukup menyulitkan karena pasar domestik hanya mampu memenuhi $40 \%$ dari total kebutuhan kacang kedelai (Nurhadi, 2012).

Faktanya, terdapat berbagai jenis legumes tropis yang tumbuh di kawasan Asia Tenggara yang berkapasitas sebagai sumber pangan bernutrisi tinggi namun belum dimanfaatkan secara optimal. Hal ini mungkin terjadi karena kecenderungan untuk terus mengembangkan potensi tanaman yang sudah lazim dikonsumsi oleh masyarakat. Salah satu jenis legumes yang terbatas pemanfaatannya adalah kecipir (Psophocarpus tetragonolobus (L.) DC.). Di Indonesia, tanaman kecipir tumbuh sepanjang tahun dengan hasil panen tahunan sebanyak $2.380 \mathrm{~kg} / \mathrm{ha}$ atau 3 kali lipat dibandingkan produksi kacang kedelai. Selain itu, hampir seluruh bagian tanaman termasuk umbi, daun, bunga, polong, biji muda, dan biji tua memiliki kandungan nutrisi yang tinggi. Walaupun demikian, atensi terhadap pengembangan potensi kecipir sebagai alternatif bahan pangan dan minuman masih rendah (Miyamoto et al., 1986).

Pemanfaatan biji kecipir tua sebagai substitusi kacang kedelai sangat mungkin direalisasikan sebab nilai gizinya setara dengan kacang kedelai. Bahkan, kandungan protein dan karbohidratnya lebih tinggi daripada kacang tanah; sedangkan profil asam amino esensialnya lebih baik jika dibandingkan dengan kacang kedelai. Dengan kandungan lisina sebanyak 413-600 mg per $100 \mathrm{~g} \mathrm{~N}$, biji kecipir mampu menutupi keterbatasan lisina pada beras, jagung dan umbi-umbian. Namun, seperti golongan legumes lainnya, biji kecipir mengandung zat anti nutrisi dan minimnya kandungan asam amino metionina, sisteina, dan triptofan (Salunkhe et al., 1992, Krisnawati, 2010).

Penggunaan biji kecipir tua di Indonesia sebagai bahan pangan cukup berkembang dan telah menghasilkan berbagai varietas produk seperti: tepung, tempe, kecap asin, miso, susu, yogurt, dan pakan ternak (Kantha dan Erdman, 1984; Haryoto, 1998; Astawan, 2009). Namun, tingkat penerimaan masyarakat terhadap produk olahan kecipir, terutama dalam bentuk susu masih rendah. Padahal, bila ditinjau dari kandungan gizinya, susu kecipir sebanding dengan susu kacang kedelai. Seperti yang terjadi pada pembuatan susu kedelai, proses pengolahan biji kecipir menimbulkan aroma langu yang kuat pada susu yang dihasilkan. Selain itu, susu kecipir cenderung tidak stabil selama masa penyimpanan pada suhu ruang (Astawan, 2009).

Penambahan hidrokoloid, yaitu karagenan sebanyak $0,02 \%$ dapat mencegah terbentuknya endapan selama penyimpanan sehingga susu kecipir tidak terpisah (Sualang, 2006). Pemilihan kappa karagenan sebagai penstabil yang paling sesuai untuk susu kecipir didasarkan pada beberapa hal: stabilitas kappa karagenan yang tinggi pada $\mathrm{pH}$ netral dan suhu $75^{\circ} \mathrm{C}$, kapasitas kappa karagenan untuk meningkatkan viskositas susu walaupun digunakan dalam konsentrasi rendah, karakteristik pemisahan susu, serta aspek hemat biaya (Phillips dan Williams, 2009).

Adapun senyawa volatil yang berkontribusi terhadap bau langu pada susu kecipir juga ditemukan dalam susu kedelai; yang merupakan produk oksidasi asam lemak tak jenuh oleh enzim lipoksigenase. Berbagai metode telah diaplikasikan untuk menginaktivasi enzim lipoksigenase pada susu kedelai, termasuk blansir dan penambahan flavor. Namun, penelitian ilmiah untuk mengurangi intensitas bau langu dari susu kecipir belum pernah dilakukan (Mtebe dan Gordon, 1987).

Untuk menyamarkan bau langu pada susu kecipir dapat pula digunakan jus jahe yang dapat dihasilkan dari tiga macam jenis jahe yaitu: jahe gajah (Zingiber officinale var. officinale), jahe emprit (Zingiber officinale var. rubrum), dan jahe merah (Zingiber officinale var. amarum). Komposisi fitokimia rimpang jahe meliputi asam amino, karbohidrat, enzim, lemak, protein, vitamin, senyawa aromatik yang bersifat volatil maupun nonvolatil, potasium oksalat, serta senyawa kompleks yang menimbulkan aroma tajam dan rasa pedas. Aktivitas enzim serta karakteristik aroma dari rimpang jahe diyakini dapat mengurangi intensitas bau langu (Pakrashi dan Pakrashi, 2003).

Berdasarkan latar belakang tersebut, penelitian ini bertujuan untuk meningkatkan akseptabilitas susu kecipir dengan adisi bahan penstabil dan jus jahe. Diharapkan dengan berkurangnya bau langu tersebut, karakteristik organoleptik susu kecipir dapat diterima dengan baik oleh masyarakat sehingga menjadi salah satu alternatif susu nabati di Indonesia. Selain itu, diversivikasi pangan dapat dicapai melalui pemanfaatan biji kecipir tua sebagai komoditas lokal yang belum dieksplorasi secara maksimal yang akhirnya dapat mengurangi ketergantungan pangan lokal terhadap kacang kedelai.

\section{Materi dan Metode \\ Materi}

Bahan-bahan yang digunakan dalam penelitian ini terdiri atas biji kecipir tua yang diperoleh dari PD. Tani Jaya Semarang, air, jahe putih (Zingiber officinale var. officinale), jahe kuning (Zingiber officinale var. rubrum), dan jahe merah (Zingiber officinale var. amarum) yang dibeli di Balai Penelitian Tanaman Rempah dan Obat (Balitro) Bogor, kappa karageenan yang diperoleh dari PT Amarta Carrageenan Indonesia, gula pasir "Gulaku", air suling, $\mathrm{K}_{2} \mathrm{SO}_{4}$ anhidrat "Merck", selenium "Merck", $\mathrm{H}_{2} \mathrm{SO}_{4}$ "Merck", $\mathrm{H}_{2} \mathrm{O}_{2}$ "Merck", asam borat "Merck", $\mathrm{NaOH}$ "Merck", larutan indikator, $\mathrm{HCl}$ "Merck", larutan AABA "Merck", larutan AccQ-fluor borate buffer "Merck", hexane "Merck", reagen Folin-Ciocalteu "Merck", Iarutan $\mathrm{Na}_{2} \mathrm{CO}_{3}$, asam galat "Merck", larutan alumunium klorida "Merck", kuersetin "Merck", DPPH, asam askorbat "Merck", metanol Pro-Analysis (PA) "Merck", vanillin "Merck", $\mathrm{HCl}$ pekat "Merck", tanin "Merck", kloroform "Merck", and 
$\mathrm{Na}_{2} \mathrm{SO}_{4}$ anhidrat "Merck" yang diperoleh dari PT Praglas Raya, Indonesia.

Selain itu, penemitian ini juga menggunakan sejumlah peralatan yang terdiri atas: blender, kain saring, Erlenmeyer, pipet volumetrik, timbangan analitik, pemanas listrik "Cimarec", pengaduk magnetik, spektrofotometer Ultraviolet-visible "Hitachi U-1800", gelas sensori plastik, kuvet "Quartz", kromameter "Konica Minolta", cawan penguapan, viskometer "Brookfield Digital Viscometer", $744 \mathrm{pH}$ meter Metrohm, oven konvensional, desikator, cawan petri, tabung destruksi, unit Kjeldahl "Velp Scientifica", unit High Pressure Liquid Chromatography ex. Merck, mikropipet, kertas saring Whatman no. 4, corong plastik, batu didih, kondensor refluks, unit Soxhlet, rotavapor "Buchi V 700/710", spatula, vorteks, botol gelap, dan unit GC-MS "Agilent 6980".

\section{Metode}

Penelitian ini berlangsung selama 4 bulan, dimulai sejak bulan Maret 2014 sampai dengan Juli 2014 dan terdiri atas penelitian pendahuluan serta dua tahap penelitian utama. Uji Consumer Rejection Threshold (CRT) diberikan kepada 30 orang panelis sebelum penelitian tahap II dilaksanakan.

\section{Perlakuan pendahuluan}

Tahap ini dilakukan dengan metode blansir yang mengadopsi metode dari penelitian sebelumnya dengan modifikasi (Miyamoto et al.,1986; Sun, 2012). Modifikasi tersebut dilakukan pada tipe leguminosa, rasio antara biji kecipir dan air, serta penambahan gula pasir. Tahap ini dimulai dengan sortasi dan pembersihan biji kecipir tua untuk menghilangkan partikel yang tidak diinginkan dan dilanjutkan dengan perendaman biji kecipir dalam air $(1: 4)$ pada suhu $25^{\circ} \mathrm{C}$ selama $20 \mathrm{jam}$. Kulit ari biji kecipir kemudian dikupas, lalu biji yang telah bersih dikelompokkan menjadi tiga; di mana masing-masing diberi perlakukan sebagai berikut: kontrol (tanpa blansir), blansir dengan media air panas selama enam menit, dan blansir dengan media uap selama satu menit. Biji kecipir kemudian diblender bersama air dengan perbandingan 1:12 dan difiltrasi menggunakan kain saring untuk membuang partikel yang tidak diinginkan. Volume susu yang dihasilkan diukur dan ditambahkan $8 \%$ gula (b/v) kemudian diaduk hingga rata. Pasteurisasi diterapkan pada susu dengan suhu $80^{\circ} \mathrm{C}$ selama 15 menit sambil terus diaduk. Sampel susu kecipir kemudian dievaluasi oleh 70 panelis melalui uji skoring dan hedonik untuk mengetahui pengaruh metode blansir terhadap karakteristik organoleptik dan penerimaan produk susu. Metode blansir yang paling efektif akan digunakan pada tahap penelitian berikutnya.

\section{Uji Sensori}

Akseptabilitas konsumer terhadap produk susu kecipir dievaluasi melalui uji skoring dan hedonik yang dilakukan pada penelitian pendahuluan, tahap I, dan tahap II. Total panelis yang dilibatkan adalah sebanyak 70 orang. Untuk uji skoring, parameter yang dinilai adalah bau langu (tidak ada bau langu sama sekali - bau langu sangat kuat), rasa asing (tidak ada rasa asing sama sekali - rasa asing sangat kuat), warna (putih - coklat muda), dan tingkat keenceran (tidak encer - sangat encer). Uji hedonik berskala 1-7 juga diberikan berdampingan dengan uji skoring; di mana skor terendah didefinisikan sebagai 'sangat tidak suka' dan skor tertinggi diartikan sebagai 'sangat suka.' Dalam pengujian buta ini, panelis diberikan beberapa sampel berkode dan diminta untuk memberikan respon pada kuisioner yang diberikan. Analisa statistik dilakukan dengan metode Analysis of Variance (ANOVA) dengan tingkat signifikansi sebesar 95\% (Lawless, 2013).

\section{Uji Stabilitas Susu Kecipir}

Larutan susu kecipir yang dibuat dengan rasio 1:4, 1:8, dan 1:12 (biji kecipir : air) tanpa adisi bahan penstabil diencerkan hingga mencapai konsentrasi 1.000, $2.000,3.000,4.000,5.000,6.000,7.000,8.000,9.000$, dan $10.000 \mathrm{ppm}$ (pada suhu $30^{\circ} \mathrm{C}$ ) kemudian diaduk dengan menggunakan batu didih hingga homogen dan diukur absorbansinya dengan menggunakan spektofometer UV-visible "Hitachi U-1800" pada 270nm. Kurva standar dibuat dengan memplot konsentrasi masing-masing larutan (sumbu $\mathbf{x}$ ) dan absorbansinya (sumbu y).

Sampel susu kecipir yang telah diberi bahan penstabil dengan 12 formulasi berbeda diencerkan hingga mencapai konsentrasi 20.000 ppm, kemudian diaduk selama 5 menit dengan menggunakan batu didih hingga homogen (pada suhu $30^{\circ} \mathrm{C}$ ). Absorbansi sampel diukur pada $270 \mathrm{~nm}$ setiap 10 menit (selama 30 menit total observasi) dan konsentrasi larutan susu dihitung dengan bantuan kurva standar. Nilai laju pengendapan susu kecipir diperoleh dengan cara memplot grafik antara waktu pengendapan dan $-\ln \left(\mathrm{Ca} / \mathrm{Ca}_{0}\right)$; di mana $\mathrm{Ca}$ merupakan konsentrasi pada saat waktu=t dan $\mathrm{Ca}_{0}$ adalah konsentrasi awal. Slope dari linearisasi grafik tersebut menunjukkan nilai laju pengendapan susu kecipir (ppm/menit). Data yang diperoleh ditulis sebagai nilai rata-rata dan standar deviasi (SD) dari replikasi sampel secara duplo (Ludvigsen, 2011).

\section{Uji Consumer Rejection Threshold (CRT) pada Jus Jahe}

Uji CRT dilakukan dengan menggunakan empat buah uji perbandingan berpasangan terhadap konsentrasi jus jahe yang berbeda $(0,5 \%, 2,0 \%, 8,0 \%$, dan $32 \%)$ dari masing-masing jenis jus jahe (jahe gajah, jahe emprit dan jahe merah). Basis yang digunakan dalam uji ini adalah formulasi susu kecipir terbaik dari hasil uji stabilitas. Sebanyak 30 orang panelis diminta untuk mencicipi sepasang sampel yang terdiri dari kontrol (susu kecipir tanpa penambahan jus jahe) dan susu kecipir yang ditambahkan jus jahe dengan konsentrasi yang diajukan 
$(0,5 \%, 2,0 \%, 8,0 \%$, dan $32 \%)$ kemudian menulis pada kuisioner; sampel mana yang lebih disukai. Air bilasan disediakan untuk menetralkan mulut setelah mencicipi tiap sampel; di mana tiap pasang sampel diberikan setiap 2 menit dengan jeda istirahat 5 menit. Semua pasangan sampel disajikan dalam konsentrasi meningkat, namun susunan pemberian sampel dan kontrol dapat diacak. Tabel distribusi binomial untuk uji perbandingan berpasangan diterapkan sebagai kriteria signifikansi atau penolakan. Hasil uji CRT akan menentukan batas toleransi konsumen terhadap konsentrasi jus jahe yang disukai sekaligus batas maksimum konsentrasi jus jahe yang akan ditambahkan dalam tahap penelitian II (Prescott et al., 2005).

\section{Analisa Warna}

Analisis warna dilakukan dengan menggunakan kromameter "Konica Minolta" pada susu kecipir dengan karakteristik organoleptik terbaik. Sekitar $15 \mathrm{ml}-20 \mathrm{ml}$ sampel susu kecipir dituangkan ke dalam cawan petri bersih kemudian skala warna diukur dengan kromameter. Hasil yang ditampilkan pada layar kromameter meliputi: $L^{*}$ untuk nilai kecerahan warna (0 menunjukkan hitam, 100 menunjukkan putih), $a^{*}$ untuk nilai kemerahan $(+)$ atau kehijauan $(-)$, dan $b^{*}$ untuk nilai kekuningan $(+)$ atau kebiruan (-). Dalam penelitian ini, indikator untuk pengukuran warna susu kecipir hanyalah nilai kecerahan $\left(L^{*}\right)$. Semua data yang diperoleh merupakan nilai ratarata dan standar deviasi dari replikasi sampel secara duplo (Yang dan Li, 2010).

\section{Analisa Viskositas}

Pengukuran viskositas susu kecipir dilakukan dengan menggunakan RV-series "Brookfield Digital" viskometer dengan spindle nomer 1 , kecepatan $100 \mathrm{rpm}$, dan suhu $45^{\circ} \mathrm{C}$. Faktor konversi spindle spesifik untuk tiap spindle serta jenis viskometer. Dengan membagi faktor 100 dengan kecepatan yang digunakan; maka diperoleh faktor konversi 1 untuk spindle no.1. Jumlah minimal sampel untuk analisa viskositas adalah $600 \mathrm{ml}$. Angka yang tampil pada layar dicatat setelah angka berhenti berubah; di mana viskositas susu kecipir diperoleh dengan mengalikan angka tersebut dengan faktor konversi spindle nyatakan dalam satuan mPa.s atau centipoise (Sugkhaphan dan Kijroongrojana, 2009).

\section{Pengukuran $\mathrm{pH}$}

Pengukuran $\mathrm{pH}$ susu kecipir dengan karakteristik organoleptik terbaik dilakukan dengan menggunakan 744 $\mathrm{pH}$ meter Metrohm berdasarkan metode SNI 01-28911992. Sebelum digunakan, $\mathrm{pH}$ meter harus dikalibrasi dengan menggunakan larutan buffer $(\mathrm{pH} 4$ dan 7); diikuti dengan membersihkan elektroda $\mathrm{pH}$ dengan air suling dan menyekanya dengan tisu. Elektroda $\mathrm{pH}$ dicelupkan ke dalam $20 \mathrm{ml}$ sampel susu kecipir lalu $\mathrm{pH}$ sampel dicatat setelah angka pada layar berhenti berubah. Semua data yang diperoleh merupakan nilai rata-rata dan standar deviasi dari replikasi sampel secara duplo (SNI, 1992).

\section{Analisa Total Padatan}

Pengukuran total padatan susu kecipir dengan karakteristik organoleptik terbaik dilakukan dengan menggunakan oven konvensional. Sebelum analisa dilakukan, suhu oven dikondisikan pada suhu $105^{\circ} \mathrm{C}$ dan cawan penguapan dikeringkan dalam oven selama 1 jam. Cawan yang telah kering harus disimpan dalam desikator sekitar 30 menit sebelum ditimbang hingga berat konstan tercapai (tingkat ketelitian hingga 0,1 mg). Sekitar 3-10 g sampel susu ditambahkan ke dalam cawan, ditimbang dengan ketelitian 0,1 $\mathrm{mg}$, dan dikeringkan dalam oven. Setelah 4 jam, cawan berisi sampel kering dimasukkan ke dalam desikator selama 30 menit, ditimbang, dan dimasukkan kembali ke dalam oven selama satu jam. Penimbangan ulang masih dilakukan sampai berat konstan tercapai dengan total waktu pengeringan hingga 16 jam, tergantung pada karakteristik sampel. Semua data dituliskan sebagai nilai rata-rata \pm standar deviasi (SD) untuk replikasi sampel secara duplo. Total padatan dihitung sebagai persentase berat sampel yang tersisa dari proses pengeringan (Wrolstad et al., 2005).

\section{Analisa Kadar Protein dengan Metode Kjeldahl}

Kandungan protein dalam sampel susu kecipir dengan karakteristik organoleptik terbaik dilakukan dengan menggunakan unit Kjeldahl "Velp Scientifica" berdasarkan metode analisa protein dalam susu (AOAC 991.200) dengan modifikasi dalam jumlah larutan indikator yang digunakan. Sampel susu kecipir dengan volume $5 \mathrm{ml}$ dituang ke dalam tabung destruksi dan dicampur dengan $7 \mathrm{~g}$ kalium sulfat $\left(\mathrm{K}_{2} \mathrm{SO}_{4}\right)$ anhidrat, $5 \mathrm{~g}$ selenium (Se) bubuk, $7 \mathrm{ml}$ asam sulfat $\left(\mathrm{H}_{2} \mathrm{SO}_{4}\right)$ pekat $98 \%$, dan $5 \mathrm{ml}$ hidrogen peroksida $\left(\mathrm{H}_{2} \mathrm{O}_{2}\right) 35 \%$ kemudian dipanaskan pada $420^{\circ} \mathrm{C}$ selama 30 menit sampai sampel menjadi hitam. Setelah tabung destruksi didinginkan sampai $50^{\circ} \mathrm{C}-60^{\circ} \mathrm{C}, 50 \mathrm{ml}$ amonia bebas air suling ditambahkan. Untuk memulai proses distilasi, sebuah Erlenmeyer yang berisi $25 \mathrm{ml} \mathrm{4 \%}$ larutan asam borat dicampur dalam unit penyulingan uap. Kemudian tabung destruksi berisi sampel yang telah didestruksi ditambahkan dengan $50 \mathrm{ml} \mathrm{NaOH} \mathrm{35 \%} \mathrm{secara} \mathrm{otomatis.}$ Proses ini berlanjut sampai $100 \mathrm{ml}$ distilat terkumpul. Distilat ini kemudian ditambahkan dengan 3 tetes larutan indikator dan dititrasi dengan $0,2 \mathrm{~N} \mathrm{HCl}$ sampai warna merah muda yang tidak pudar terbentuk. Semua data disajikan sebagai nilai rata-rata \pm standar deviasi (SD) untuk replikasi secara duplo (AOAC, 2005).

\section{Analisa Komposisi Asam Amino}

Analisa terhadap profil asam amino susu kecipir dilakukan dengan menggunakan unit High Pressure Liquid Chromatography (HPLC) "Merck". Sampel dengan berat $0,1 \mathrm{~g}$ ditambahkan dengan $5 \mathrm{ml} \mathrm{HCN} 6 \mathrm{~N}$ ke dalam gelas piala kemudian dihomogenisasi dengan 
menggunakan vorteks. Hidrolisis dilakukan selama 22 jam pada suhu $110^{\circ} \mathrm{C}$. Setelah dingin, sampel diencerkan dengan air suling hingga mencapai volume $50 \mathrm{ml}$ dan disaring melalui $0.45 \mu \mathrm{m}$ kertas saring. Sebanyak $500 \mu \mathrm{l}$ filtrat ditambahkan dengan $40 \mu \mathrm{l}$ larutan a-amino- $N$ butyric acid (AABA), kemudian diencerkan dengan air suling hingga mencapai volume $1.000 \mu \mathrm{l}$. Sebanyak $10 \mu \mathrm{l}$ campuran dipipet dan ditambahkan dengan $70 \mu$ larutan AccQ-fluor borate buffer. Sebanyak $20 \mu \mathrm{l}$ larutan fluor $A$ reagen ditambahkan ke dalam larutan dan didiamkan selama 1 menit. Setelah inkubasi selama 10 menit pada $55^{\circ} \mathrm{C}, 5 \mu \mathrm{l}$ sampel disuntikkan ke perangkat HPLC. Larutan standar dibuat dengan prosedur dan reagen yang sama, namun sampel diganti dengan $40 \mu \mathrm{l}$ standar campuran asam amino (Nollet, 1996).

\section{Analisa Kadar Lemak dengan metode Weibull-Stoldt}

Analisa kadar lemak susu kecipir dengan karakteristik organoleptik terbaik dilakukan dengan menggunakan metode Weibull-Stoldt dengan modifikasi pada jenis pelarut. Sebanyak $20 \mathrm{~g}$ sampel susu dimasukkan ke dalam Erlenmeyer yang berisi batu didih (keduanya telah dimasukkan ke dalam oven dan ditimbang hingga mencapai berat konstan), ditambahkan air suling hingga mencapai volume $100 \mathrm{ml}$ dan diikuti dengan penambahan $100 \mathrm{ml} \mathrm{HCl} 20 \%$. Penentuan blanko juga dilakukan dengan menggunakan prosedur dan reagen yang sama, namun sampel diganti dengan $25 \mathrm{ml}$ air suling. Erlenmeyer kemudian dihubungkan ke kondensor refluks untuk direfluks selama 30 menit dengan sesekali digoyangkan. Proses refluks dihentikan setelah warna larutan berubah menjadi coklat gelap kehitaman. Penyaringan sampel yang telah direfluks dilakukan dengan menggunakan air suling bersuhu $80^{\circ} \mathrm{C}$ melalui kertas saring Whatman nomor 4 hingga air bilasan menunjukkan $\mathrm{pH} 7$ (diukur dengan menggunakan $\mathrm{pH}$ meter). Kertas saring berisi sampel tersebut kemudian dimasukkan ke dalam oven selama 1 jam, dilipat, diikat dan ditempatkan dalam timbal ekstraksi Soxhlet. Ekstraksi lemak dilakukan dengan perangkat Soxhlet dengan menggunakan heksana sebagai pelarut. Setelah 4 jam, pelarut diuapkan menggunakan rotvapor "Buchi $\mathrm{V}$ 700/710," kemudian labu berisi sampel bebas pelarut dikeringkan dalam oven, didinginkan dalam desikator, dan ditimbang kembali hingga berat konstan diperoleh. Semua data disajikan sebagai nilai rata-rata \pm standar deviasi (SD) untuk replikasi secara duplo (Monakhova et al., 2013).

\section{Analisa Total Fenolik dengan Metode Folin-Ciocalteu}

Dalam analisa total fenolik, sebanyak $0.1 \mathrm{ml}$ sampel susu kecipir diencerkan hingga 1.000 ppm; diikuti dengan penambahan $0,1 \mathrm{ml}$ Folin Ciocalteu-reagen $(50 \%)$ ke dalam tabung reaksi. Setelah divorteks selama 3 menit, campuran ditambahkan dengan $2 \mathrm{ml}$ larutan $\mathrm{Na}_{2} \mathrm{CO}_{3} 2 \%$ kemudian diinkubasi dalam ruang gelap selama 30 menit. Blanko dibuat dengan prosedur yang sama, namun sampel diganti dengan air suling. Absorbansi dibaca pada $750 \mathrm{~nm}$ dengan menggunakan "Thermo Scientific Genesys 20" spektrofotometer. Kurva kalibrasi dibuat dengan memplot grafik antara konsentrasi asam galat (25 ppm, 50 ppm, 75 ppm, dan 100 ppm) dan absorbansi nya. Total fenolik dihitung sebagai $\mathrm{mg}$ ekuivalen asam galat / g sampel (mg EAG / g sampel) dan semua data disajikan sebagai nilai rata-rata \pm standar deviasi (SD) untuk replikasi secara duplo (Rorong dan Suryanto, 2010).

Analisa Total Flavonoid dengan Metode Aluminum Chloride Colorimetric

Sebanyak $2 \mathrm{ml}$ sampel susu kecipir ditambahkan dengan $2 \mathrm{ml}$ larutan aluminium klorida 2\% yang telah diencerkan dengan metanol ke dalam tabung reaksi. Blanko dibuat dengan prosedur yang sama, namun sampel diganti dengan air suling. Campuran tersebut kemudian divorteks dan absorbansinya dibaca pada 415 $\mathrm{nm}$ dengan menggunakan "Thermo Scientific Genesys 20" spektrofotometer. Kurva kalibrasi dibuat dengan memplot grafik antara konsentrasi kuersetin $(25$ ppm, 50 ppm, 75 ppm, dan 100 ppm) dan absorbansinya. Kandungan flavonoid sampel dihitung sebagai $\mathrm{mg}$ ekuivalen kuersetin sampel / g (mg EK / g sampel) dan semua data disajikan sebagai nilai rata-rata \pm standar deviasi (SD) untuk replikasi secara duplo (Rorong dan Suryanto, 2010).

\section{Analisa Aktivitas Antioksidan dengan metode DPPH}

Sampel susu kecipir diencerkan dalam 100\% metanol (PA) pada suhu ruangan untuk menghasilkan konsentrasi $1000 \mathrm{ppm}$. Sebanyak $0,15 \mathrm{ml}$ volume sampel yang telah diencerkan ditambahkan dengan $0,9 \mathrm{ml}$ larutan metanolik DPPH $(0,1 \mathrm{mM})$; sedangkan kontrol dibuat dengan mencampurkan $0,15 \mathrm{ml} 0,1 \mathrm{mM}$ larutan DPPH dan 0,9 ml metanol (PA). Setelah campuran diinkubasi selama 20 menit, absorbansi kemudian diukur pada $517 \mathrm{~nm}$ dengan menggunakan "Thermo Scientific Genesys 20" spektrofotometer. Kurva standar dibuat dengan memplot \% SA DPPH dan berbagai konsentrasi vitamin C (10 ppm, 15 ppm, 20 ppm, dan 25 ppm). Semua data disajikan sebagai nilai rata-rata \pm standar deviasi (SD) untuk replikasi secara duplo (Tangkanakul et al., 2009).

Analisa Kandungan Tanin dengan Metode Vanillin

Analisis terhadap kandungan tanin dilakukan dengan menambahkan $0,1 \mathrm{ml}$ sampel susu kecpir dan 2 $\mathrm{ml}$ larutan metanolik-vanillin $4 \%(\mathrm{~b} / \mathrm{v})$ ke dalam tabung reaksi yang sudah dibungkus dengan aluminium foil. Setelah campuran divorteks, $1 \mathrm{ml} \mathrm{HCl}$ pekat $37 \%$ ditambahkan dan kembali divorteks. Blanko dibuat dengan prosedur yang sama, namun sampel diganti dengan air suling. Setelah inkubasi selama 20 menit, absorbansi dibaca pada $500 \mathrm{~nm}$ dengan menggunakan "Thermo Scientific Genesys 20" spektrofotometer. Kurva 
kalibrasi dibuat dengan memplot grafik antara konsentrasi katekin (25 ppm, 50 ppm, 75 ppm, dan 100 ppm) dan absorbansi nya. Kandungan tanin dihitung sebagai $\mathrm{mg}$ ekuivalen katekin / g sampel (mg KE/ g sampel) dan semua data disajikan sebagai mean \pm standar deviasi (SD) untuk dua ulangan (duplo) (Rorong dan Suryanto, 2010).

\section{Analisa Metabolit Sekunder dengan GC-MS}

Analisa profil metabolit sekunder dilakukan di Pusat Laboratorium Forensik (PUSLABFOR) BARESKRIM POLRI dengan menggunakan Agilent 6980 GC. Ekstraksi sampel dengan kloroform dilakukan untuk mendapatkan sekitar $5 \mathrm{ml}$ ekstrak susu kecipir sebelum dianalisa dengan GC-MS. Susu kecipir dan kloroform dengan proporsi yang sama dicampur dan disaring dengan menggunakan kertas saring Whatman nomer 4 dengan penambahan 10 gram $\mathrm{Na}_{2} \mathrm{SO}_{4}$ anhidrat untuk menghilangan kandungan air dari susu kecipir. Ekstrak sampel disimpan dalam botol gelap sebelum analisis dengan GC-MS "Agilent 6980". Sebanyak 1,0 $\mu \mathrm{l}$ ekstrak sampel susu kecipir disuntikkan dengan slpit ratio 50:1 dan pemisahan dilakukan selama 64,74 menit dengan suhu akhir $290^{\circ} \mathrm{C}$. Identifikasi dilakukan dengan membandingkan data spektrum senyawa yang terdeteksi dengan referensi. Semua analisa data dilakukan dengan menggunakan program Agilent Chemstation (Ekade dan Manik, 2014).

\section{Analisa Statistik}

Analysis of Variance (ANOVA) dilakukan untuk mengevaluasi signifikansi dalam semua uji sensori dan laju pengendapan susu kecipir; diikuti oleh uji lanjutan Duncan. Seluruh perhitungan statistik silakukan dengan program SPSS 16,0; di mana kriteria yang diterapkan untuk perbedaan yang signifikan adalah nilai probabilitas $p<0,05$.

\section{Hasil dan Pembahasan}

Efek Metode Blansir terhadap Tingkat Akseptabilitas Konsumer terhadap Susu Kecipir

Tabel 1 menunjukkan nilai rata-rata dari setiap parameter yang diujikan untuk uji skoring (Tabel 1a) dan hedonik (Tabel 1b). Berdasarkan hasil uji statistik, nilai skoring untuk parameter bau langu berbeda signifikan antara ketiga sampel susu pada tingkat signifikansi $95 \%$. Namun, hasil uji hedonik berskala 1-7 menunjukkan perbedaan nyata $(a=0,05)$ pada tingkat kesukaan panelis terhadap warna ketiga sampel susu; di mana susu kecipir tanpa metode blansir memiliki nilai paling tinggi $(5,00 \pm 1,3)$ dan didefinisikan sebagai "sedikit suka."

Perlakuan pendahuluan dengan memblansir biji kecipir tidak mempengaruhi penerimaan konsumen secara signifikan; terkait dengan parameter aroma, rasa, viskositas, dan penerimaan keseluruhan. Penjelasan mengenai penyebab bau langu dan rasa asing saling terkait satu sama lain; dimana keduanya dihasilkan dari aktivitas enzim lipoxygenase. Enzim ini secara umum terkandung dalam legumes dan berperan sebagai katalis untuk oksidasi asam lemak tak jenuh; terutama asam linoleat dalam legumes. Hidroperoksida yang terbentuk mengalami degradasi dan menghasilkan beberapa senyawa volatil seperti aldehida, keton, dan alkohol yang berkontribusi terhadap bau langu dan rasa asing pada produk olahan kedelai dan legumes lainnya (Ghafoor et al., 2011). Lv et al. (2011) melaporkan bahwa bau langu susu kedelai dapat dikurangi dengan metode blansir air panas dan penggilingan kedelai pada suhu di atas $80^{\circ} \mathrm{C}$.

Tabel 1. Efek Metode Blansir terhadap Nilai Skoring dan Hedonik Susu Kecipir

\begin{tabular}{cccc}
\hline \multirow{2}{*}{ Nilai Skoring } & \multicolumn{3}{c}{$(\mathrm{a})$} \\
\cline { 2 - 4 } & Tanpa Blansir & Blansir Air Panas & Blansir Uap \\
\hline Bau Langu & $4,60 \pm 1,39^{\mathrm{b}}$ & $3,59 \pm 1,65^{\mathrm{a}}$ & $3,71 \pm 1,63^{\mathrm{a}}$ \\
Rasa Asing & $4,21 \pm 1,55^{\mathrm{a}}$ & $3,84 \pm 1,60^{\mathrm{a}}$ & $3,76 \pm 1,53^{\mathrm{a}}$ \\
Warna & $2,59 \pm 1,39^{\mathrm{a}}$ & $2,20 \pm 1,19^{\mathrm{a}}$ & $2,20 \pm 1,20^{\mathrm{a}}$ \\
Tingkat Keenceran & $4,57 \pm 1,03^{\mathrm{a}}$ & $4,97 \pm 1,18^{\mathrm{a}}$ & $4,94 \pm 1,13^{\mathrm{a}}$ \\
\hline
\end{tabular}

(b)

\begin{tabular}{cccc}
\hline \multirow{2}{*}{ Nilai Hedonik } & \multicolumn{3}{c}{ Perlakuan } \\
\cline { 2 - 4 } & Tanpa Blansir & Blansir Air Panas & Blansir Uap \\
\hline Warna & $5,00 \pm 1,30^{\mathrm{b}}$ & $4,46 \pm 1,46^{\mathrm{a}}$ & $4,64 \pm 1,26^{\mathrm{ab}}$ \\
Aroma & $3,40 \pm 1,49^{\mathrm{a}}$ & $3,90 \pm 1,37^{\mathrm{a}}$ & $3,80 \pm 1,42^{\mathrm{a}}$ \\
Rasa & $3,17 \pm 1,60^{\mathrm{a}}$ & $3,99 \pm 1,47^{\mathrm{a}}$ & $4,19 \pm 1,43^{\mathrm{a}}$ \\
Viskositas & $4,44 \pm 1,37^{\mathrm{a}}$ & $4,14 \pm 1,44^{\mathrm{a}}$ & $4,29 \pm 1,24^{\mathrm{a}}$ \\
Keseluruhan & $4,13 \pm 1,50^{\mathrm{a}}$ & $4,13 \pm 1,38^{\mathrm{a}}$ & $4,04 \pm 1,40^{\mathrm{a}}$ \\
\hline
\end{tabular}

Keterangan: Notasi huruf yang berbeda pada tiap parameter menunjukkan perbedaan nyata pada $a=0,05$; nilai skoring 1: tidak ada bau langu sama sekali / tidak ada rasa asing sama sekali / warna susu cenderung putih / tidak encer, 6: bau langu sangat kuat / rasa asing sangat kuat / warna susu coklat muda / sangat encer; nilai hedonik 1: sangat tidak suka, 7: sangat suka 
Hasil uji statistik pada preferensi konsumen terhadap aroma dan rasa menunjukkan bahwa metode blansir untuk biji kecipir; baik dengan air panas pada suhu $80^{\circ} \mathrm{C}$ selama 6 menit atau dengan uap selama 1 menit tidak mempengaruhi eksistensi enzim lipoxygenase secara signifikan $(a=0,05)$. Dengan demikian, metode blansir tidak memberikan hasil yang diharapkan untuk mengurangi bau langu bila diterapkan pada biji kecipir. Hal ini mungkin disebabkan oleh efek pasteurisasi yang diterapkan pada suhu $80^{\circ} \mathrm{C}$ selama 15 menit terhadap semua sampel susu kecipir dan menimbulkan efek yang sama terhadap karakteristik rasa susu sehingga panelis tidak menemukan perbedaan yang signifikan antarsampel. Dengan demikian, blansir tidak perlu diterapkan sebagai perlakuan pendahuluan dalam produksi susu kecipir.

Efek Rasio antara Biji Kecipir dan Air serta Konsentrasi Bahan Penstabil terhadap Laju Pengendapan Susu Kecipir

Terdapat interaksi yang signifikan antara rasio biji kecipir dengan air dan persentase kappa karagenan $(a=0,05)$ dalam mempengaruhi laju pengendapan susu kecipir. Pengaruh setiap kombinasi perlakuan terhadap laju pengendapan susu kecipir dapat dilihat pada Figur 1. Susu kecipir dengan stabilitas terbaik memiliki laju pengendapan terendah; artinya dibutuhkan waktu lebih lama bagi suspensi untuk terpisah dan membentuk sedimen. Dari setiap rasio (biji kecipir tua : air) yang diaplikasikan, formulasi dengan laju pengendapan terendah berdasarkan analisa statistik $(a=0,05)$ akan diuji secara organoleptik melalui tes skoring dan hedonik. Tiga formulasi terbaik yang dievaluasi lebih lanjut adalah susu kecipir dengan rasio 1:8-0,01\% kappa karagenan, rasio
1:4 - 0,01\% kappa karagenan, dan rasio 1:12 - 0,02\% kappa karagenan. Pemilihan kappa karagenan sebagai penstabil yang paling sesuai untuk susu kecipir didasarkan pada beberapa hal: stabilitas kappa karagenan yang tinggi pada $\mathrm{pH}$ netral dan suhu $75^{\circ} \mathrm{C}$, kapasitas kappa karagenan untuk meningkatkan viskositas susu walaupun digunakan dalam konsentrasi rendah, karakteristik pemisahan susu, serta aspek hemat biaya (Phillips dan Williams, 2009).

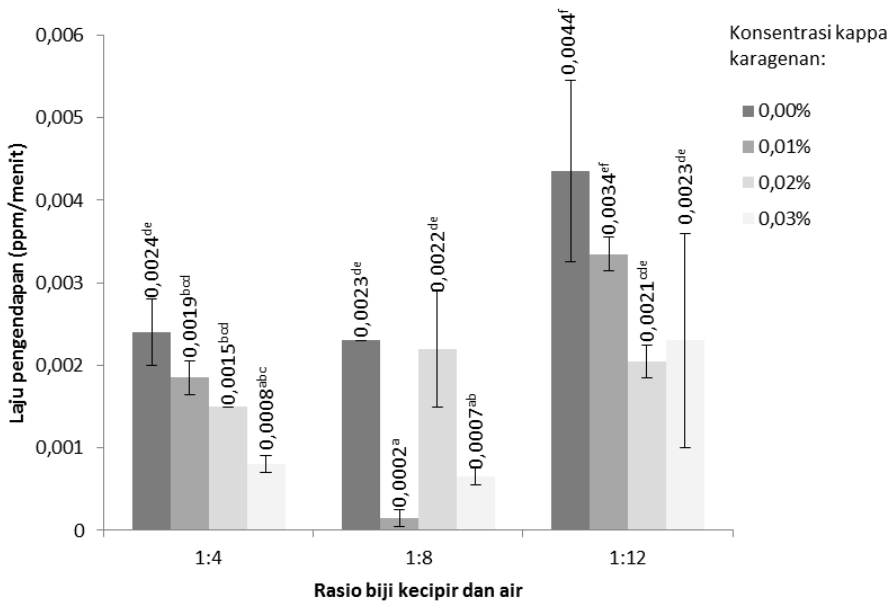

Figur 1. Efek dari kombinasi perlakuan antara rasio biji kecipir dan air dengan konsentrasi kappa karagenan terhadap laju pengendapan susu kecipir. Keterangan: notasi huruf yang berbeda pada grafik menunjukkan perbedaan nyata pada $\mathrm{a}=0,05$

Hasil uji statistik menunjukkan adanya interaksi $(a=0,05)$ antara rasio biji kecipir dan air dengan konsentrasi kappa karagenan dalam mempengaruhi laju

Tabel 2. Efek Kombinasi Berbagai Rasio Biji Kecipir dan Air dengan Konsentrasi Kappa Karagenan terhadap Nilai Uji Skoring dan Hedonik Susu Kecipir

(a)

\begin{tabular}{cccc}
\hline \multirow{2}{*}{ Nilai Skoring } & \multicolumn{3}{c}{ Rasio (Biji Kecipir Tua : Air); \% Kappa Karagenan } \\
\cline { 2 - 4 } & $1: 4 ; 0,01 \%$ & $1: 8 ; 0,01 \%$ & $1: 12 ; 0,02 \%$ \\
\hline Bau Langu & $4,43 \pm 1,44^{\mathrm{a}}$ & $4,07 \pm 1,56^{\mathrm{a}}$ & $3.90 \pm 1,72^{\mathrm{a}}$ \\
Rasa Asing & $4,53 \pm 1,22^{\mathrm{b}}$ & $3,46 \pm 1,55^{\mathrm{a}}$ & $3.13 \pm 1,41^{\mathrm{a}}$ \\
Warna & $3,51 \pm 1,49^{\mathrm{b}}$ & $2,46 \pm 1,07^{\mathrm{a}}$ & $2.11 \pm 1,11^{\mathrm{a}}$ \\
Tingkat Keenceran & $2,77 \pm 1,21^{\mathrm{a}}$ & $4,37 \pm 1,07^{\mathrm{b}}$ & $4.54 \pm 1,28^{\mathrm{b}}$ \\
\hline
\end{tabular}

(b)

\begin{tabular}{cccc}
\hline \multirow{2}{*}{ Nilai Hedonik } & \multicolumn{3}{c}{ Rasio (Biji Kecipir Tua : Air); \% Kappa Karagenan } \\
\cline { 2 - 4 } & $1: 4 ; 0,01 \%$ & $1: 8 ; 0,01 \%$ & $1: 12 ; 0,02 \%$ \\
\hline Warna & $4,53 \pm 1,28^{\mathrm{a}}$ & $4,93 \pm 1,32^{\mathrm{a}}$ & $4,59 \pm 1,34^{\mathrm{a}}$ \\
Aroma & $3,29 \pm 1,40^{\mathrm{a}}$ & $3,90 \pm 1,83^{\mathrm{a}}$ & $3,56 \pm 1,59^{\mathrm{a}}$ \\
Rasa & $2,80 \pm 1,38^{\mathrm{a}}$ & $4,16 \pm 1,68^{\mathrm{b}}$ & $4,23 \pm 1,60^{\mathrm{b}}$ \\
Viskositas & $3,34 \pm 1,52^{\mathrm{a}}$ & $4,56 \pm 1,26^{\mathrm{b}}$ & $4,36 \pm 1,27^{\mathrm{b}}$ \\
Keseluruhan & $2,96 \pm 1,24^{\mathrm{a}}$ & $4,27 \pm 1,49^{\mathrm{b}}$ & $4,19 \pm 1,41^{\mathrm{b}}$ \\
\hline
\end{tabular}

Keterangan: Notasi huruf yang berbeda pada tiap parameter menunjukkan perbedaan nyata pada $a=0,05$; nilai skoring 1: tidak ada bau langu sama sekali / tidak ada rasa asing sama sekali / warna susu cenderung putih / tidak encer, 6: bau langu sangat kuat / rasa asing sangat kuat / warna susu coklat muda / sangat encer; nilai hedonik 1: 
pengendapan susu kecipir. van de Velde dan De Ruiter (2005) melaporkan bahwa penurunan selisih berat jenis dan peningkatan viskositas dapat mengurangi laju pengendapan suspensi. Penambahan karagenan sebagai bahan penstabil sangat penting untuk membentuk helix dengan kelompok sulfat bermuatan negatif; di mana helix ini akan berinteraksi dengan partikel protein dalam susu hingga batas tertentu dan mencegah terjadinya sedimentasi (Ludvigsen, 2011). Berdasarkan pengamatan secara visual, kombinasi kedua faktor; yaitu konsentrasi kappa karageenan dan proporsi kecipir yang semakin besar akan menghasilkan susu kecipir dengan viskositas yang semakin tinggi. Akibatnya, pengendapan partikel dalam suspensi dapat ditekan; di mana tipe pengendapan berubah dari free settling menjadi hindered settling (Sowonola et al., 2005; van de Velde and De Ruiter, 2005).

Suspensi yang paling encer; yaitu dibuat dengan rasio biji kecipir dan air sebanyak 1:12 mengalami free settling; di mana partikel bergerak cukup jauh dari partikel lain maupun dinding wadah. Namun, susu kecipir yang paling terkonsentrasi (rasio 1:4) mengalami hindered settling karena banyaknya partikel dalam suspensi. Ketika sistem menjadi padat, gerakan tiap partikel terhambat satu sama lain dan sedimentasi terjadi secara lambat. Oleh karena itu, proporsi biji kecipir yang tinggi dalam formulasi dapat menghasilkan susu yang lebih terkonsentrasi dengan laju pengendapan yang lebih rendah.

Menariknya, susu kecipir yang terbuat dari rasio $1: 8$ (biji kecipir tua : air) dan 0,01\% kappa karagenan memiliki laju pengendapan terendah; yaitu 0,0002 \pm
$0,0001 \mathrm{ppm} / \mathrm{m}$; namun tidak berbeda nyata dengan susu yang terbuat dari rasio 1:8-0,03\% kappa karagenan dan rasio 1:4 - 0,03\% kappa karagenan. Suspensi susu dengan rasio 1:8 memiliki konsistensi di antara kedua rasio lain dan dapat diklasifikasikan sebagai hindered settling sehingga cenderung memiliki tingkat presipitasi yang rendah. Interaksi dengan kappa karagenan bahkan dalam konsentrasi rendah $(0,01 \%)$ tampaknya menghasilkan susu kecipir dengan stabilitas yang optimum. Hal ini juga sesuai dengan hasil penelitian sebelumnya oleh Sualang (2006); di mana stabilitas terbaik dicapai dengan penambahan 0,01\% kappa karagenan ke dalam susu kedelai dengan rasio 1:8 (kedelai : air). Interaksi antara kelompok sulfat bermuatan negatif dari helix yang terbentuk dengan protein pada susu kecipir mencapai tingkat di mana seluruh partikel protein terikat selama proses sedimentasi.

Efek Rasio antara Biji Kecipir dan Air serta Konsentrasi Bahan Penstabil terhadap Tingkat Penerimaan Konsumen

Tabel 2 menunjukkan nilai rata-rata uji skoring (Tabel 2a) dan hedonik (Tabel 2b) terhadap ketiga sampel susu kecipir dengan stabilitas terbaik. Terdapat perbedaan signifikan antarsampel susu kecipir terkait dengan intensitas rasa langu, warna, dan viskositas dengan tingkat kepercayaan $95 \%$. Uji statistik terhadap tes hedonik juga menunjukkan perbedaan signifikan antarsampel $(a=0,05)$ terhadap rasa, viskositas, dan penerimaan keseluruhan.

Rasio biji kecipir dan air yang lebih besar (1:4) menghasilkan susu kecipir dengan rasa asing dan pahit

Tabel 3. Efek Kombinasi Berbagai Tipe dan Konsentrasi Jus Jahe terhadap Nilai Uji Skoring dan Hedonik Susu Kecipir

(a)

Jenis dan Konsentrasi (\%) Jus Jahe

\begin{tabular}{ccccc} 
Nilai Skoring & 0\% Jus Jahe & $\begin{array}{c}26,91 \% \text { Jus Jahe } \\
\text { Gajah }\end{array}$ & $\begin{array}{c}12,27 \% \text { Jus Jahe } \\
\text { Emprit }\end{array}$ & $\begin{array}{c}5,77 \% \text { Jus Jahe } \\
\text { Merah }\end{array}$ \\
\cline { 2 - 5 } & & $3,26 \pm 1,66^{\mathrm{a}}$ & $3,16 \pm 1,71^{\mathrm{a}}$ & $3,64 \pm 1,51^{\mathrm{ab}}$ \\
Bau Langu & $4,07 \pm 1,56^{\mathrm{b}}$ & $3,27 \pm 1,67^{\mathrm{a}}$ & $2,86 \pm 1,48^{\mathrm{a}}$ & $3,30 \pm 1,59^{\mathrm{a}}$ \\
Rasa Asing & $3,46 \pm 1,55^{\mathrm{a}}$ & $3,30 \pm 1,30^{\mathrm{b}}$ & $2,70 \pm 1,27^{\mathrm{a}}$ & $2,53 \pm 1,26^{\mathrm{a}}$ \\
Warna & $2,46 \pm 1,07^{\mathrm{a}}$ & $4,26 \pm 1,37^{\mathrm{a}}$ & $4,17 \pm 1,42^{\mathrm{a}}$ & $4,04 \pm 1,46^{\mathrm{a}}$ \\
\hline
\end{tabular}

(b)

\begin{tabular}{ccccc}
\hline \multirow{2}{*}{ Nilai Hedonik } & \multicolumn{4}{c}{ Jenis dan Konsentrasi (\%) Jus Jahe } \\
\cline { 2 - 5 } & 0\% Jus Jahe & $\begin{array}{c}26,91 \% \text { Jus Jahe } \\
\text { Gajah }\end{array}$ & $\begin{array}{c}12,27 \% \text { Jus Jahe } \\
\text { Emprit }\end{array}$ & $\begin{array}{c}5,77 \% \text { Jus Jahe } \\
\text { Merah }\end{array}$ \\
\hline Warna & $4,93 \pm 1,32^{\mathrm{a}}$ & $5,04 \pm 1,24^{\mathrm{a}}$ & $5,41 \pm 1,21^{\mathrm{a}}$ & $5,33 \pm 1,26^{\mathrm{a}}$ \\
Aroma & $3,90 \pm 1,83^{\mathrm{a}}$ & $4,26 \pm 1,58^{\mathrm{ab}}$ & $4,67 \pm 1,66^{\mathrm{b}}$ & $4,33 \pm 1,36^{\mathrm{ab}}$ \\
Rasa & $4,16 \pm 1,68^{\mathrm{a}}$ & $4,37 \pm 1,37^{\mathrm{ab}}$ & $4,96 \pm 1,30^{\mathrm{c}}$ & $4,77 \pm 1,51^{\mathrm{bc}}$ \\
Viskositas & $4,56 \pm 1,26^{\mathrm{a}}$ & $4,79 \pm 1,24^{\mathrm{a}}$ & $4,81 \pm 1,17^{\mathrm{a}}$ & $4,90 \pm 1,02^{\mathrm{a}}$ \\
Keseluruhan & $4,27 \pm 1,49^{\mathrm{a}}$ & $4,81 \pm 1,15^{\mathrm{b}}$ & $5,04 \pm 1,00^{\mathrm{b}}$ & $4,97 \pm 1,14^{\mathrm{b}}$ \\
\hline
\end{tabular}

Keterangan: Notasi huruf yang berbeda pada tiap parameter menunjukkan perbedaan nyata pada $a=0,05$; nilai skoring 1: tidak ada bau langu sama sekali / tidak ada rasa asing sama sekali / warna susu cenderung putih / tidak encer, 6: bau langu sangat kuat / rasa asing sangat kuat / warna susu coklat muda / sangat encer; nilai hedonik 1: sangat tidak suka, 7 : sangat suka 
yang lebih intens, warna yang lebih gelap, serta viskositas yang lebih tinggi. Efek-efek yang tidak menyenangkan pada karakteristik organoleptik menghasilkan tingkat penerimaan yang lebih rendah terhadap produk susu. Meskipun tidak ada perbedaan yang signifikan pada preferensi susu kecipir dengan rasio $1: 12-0,02 \%$ kappa karagenan dan rasio $1: 8-0,01 \%$ kappa karagenan, nilai tertinggi diberikan pada formulasi $1: 8$ - 0,01\% kappa karagenan sehingga menjadi formulasi dasar yang akan diterapkan dalam uji CRT dan penelitian tahap II.

\section{Tingkat Penerimaan Jus Jahe}

Uji CRT merupakan metode yang tepat untuk mendeteksi nilai ambang batas penambahan konsentrasi jus jahe yang sangat mempengaruhi tingkat preferensi konsumen terhadap produk akhir. Tabel distribusi binomial untuk uji preferensi berpasangan (dua sisi, $p=0,5)$ digunakan untuk menentukan signifikansi derajat akseptabilitas dan penolakan terhadap konsentrasi jus jahe. Hasil yang diperoleh dari uji CRT menunjukkan bahwa tingkat toleransi konsumen terhadap masingmasing jenis jus jahe bervariasi; di mana susu kecipir dengan penambahan jus jahe putih hingga konsentrasi maksimum 26,91\% (v/v) masih dapat diterima oleh konsumen; diikuti oleh $12,27 \%(v / v)$ untuk jus jahe kuning dan $5,57 \%(v / v)$ untuk jus jahe merah. Hasil ini sesuai dengan intensitas aroma jahe dan tingkat rasa pedas dari masing-masing jenis jahe. Rostiana et al. (1991) melaporkan bahwa jahe putih memiliki aroma jahe yang lembut dan rasa kurang tajam. Namun, kedua karakteristik ini lebih intens pada jahe kuning dan paling kuat pada jahe merah.

Tingkat Akseptabilitas Konsumer terhadap Karakteristik Organoleptik

Hasil uji sensori terhadap keempat sampel susu kecipir; yaitu susu kecipir dengan penambahan $26,91 \%$ jus jahe putih, $12,27 \%$ jus jahe kuning, $5,57 \%$ jus jahe merah, dan kontrol (tanpa penambahan jus jahe) ditunjukkan pada Tabel 3. Berdasarkan hasil uji statistik $(a=0,05)$, terdapat perbedaan signifikan pada intensitas bau langu dan warna antarsampel serta tingkat preferensi konsumen terhadap aroma, rasa, dan penerimaan keseluruhan. Selain itu, susu kecipir dengan penambahan $12,27 \%$ jus jahe emprit dinilai memiliki karakteristik organoleptik terbaik pada uji hedonik.

Berdasarkan hasil uji statistik, dapat disimpulkan bahwa penerimaan keseluruhan ketiga sampel susu kecipir yang ditambahkan jus jahe secara signifikan lebih baik daripada sampel kontrol dengan tingkat preferensi mulai dari dari netral sampai sedikit suka. Dalam pembahasan sebelumnya telah dijelaskan bahwa aroma khas dan tingkat ketajaman rasa pedas jahe dapat mengurangi intensitas bau langu susu kecipir; sehingga meningkatkan karakteristik rasa serta akseptabilitas konsumen.
Dengan mempertimbangkan tingkat penerimaan terhadap parameter lainnya, susu kecipir dengan rasio 1:8 (biji kecipir tua : air), 0,01\% kappa karagenan, dan $12,27 \%$ jus jahe kuning dinilai memiliki karakteristik organoleptik terbaik. Analisia lebih lanjut dilakukan untuk mengetahui karakteristik fisikokimia susu; di antaranya adalah pengukuran pada warna, viskositas, $\mathrm{pH}$, total padatan, kadar protein, komposisi asam amino, kadar lemak, kapasitas antioksidan, total flavonoid, total fenolik, kandungan tanin, serta senyawa metabolit sekunder.

Tabel 4 . Sifat Fisikokimia Susu Kecipir dengan Karakteristik Organoleptik Terbaik

\begin{tabular}{lc}
\hline Sifat Fisikokimia & Hasil \\
\hline Warna & $52,75 \pm 1,17$ \\
Viskositas (mPa.s) & $16,18 \pm 0,04$ \\
pH & $6,92 \pm 0,01$ \\
Total Padatan (\%) & $10,29 \pm 0,04$ \\
Protein (\%) & $1,58 \pm 0,02$ \\
Lemak (\%) & $0,88 \pm 0,03$ \\
Total Fenolik (mg GA/g sampel) & $0,27 \pm 0,01$ \\
Total Flavonoid (mg QE/g sampel) & $0,24 \pm 0,01$ \\
Kapasitas Antioksidan (\%SA) & $26,62 \pm 1,95$ \\
Tannin (mg CE/g sampel) & $0,24 \pm 0,03$ \\
\hline
\end{tabular}

Sifat Fisikokimia Susu Kecipir dengan Karakteristik Organoleptik Terbaik

Tabel 4 secara singkat menampilkan data fisikokimia susu kecipir yang dibuat dengan rasio 1:8 (biji kecipir tua : air), 0,01\% kappa karagenan, dan 12,27\% jus jahe kuning. Nilai kecerahan sampel susu kecipir adalah $52,75 \pm 1,17$ dan menunjukkan warna yang lebih gelap jika dibandingkan dengan nilai kecerahan susu kedelai pada umumnya $(90,4-93,00)$ seperti yang dilaporkan oleh Aziadekey (2001). Selain itu, Kneifel, Ulberth dan Scchaffer (1992) menjelaskan beberapa faktor yang menyebabkan rendahnya nilai kecerahan produk susu; di antaranya adalah rendahnya kandungan lemak dari susu kecipir yang hanya di bawah $1 \%$ sehingga cenderung menghasilkan tingkat penghamburan cahaya yang rendah.

Viskositas susu kecipir dengan penambahan $12,27 \%$ jus jahe kuning adalah $16,18 \pm 0,04 \mathrm{mPa} . \mathrm{s}\left(25^{\circ} \mathrm{C}\right.$, $100 \mathrm{rpm})$. Hasil ini mendekati viskositas dari empat produk susu kedelai komersial seperti yang dilaporkan oleh Liu and Chang (2007); di mana viskositasnya berkisar pada $16,5-26,4 \mathrm{mPa} . \mathrm{s}\left(25^{\circ} \mathrm{C}, 100 \mathrm{rpm}\right)$. Oleh karena itu, dapat disimpulkan bahwa rasio untuk biji kecipir dan air (1:8) serta persentase kappa karagenan yang diterapkan dalam formulasi $(0,01 \%)$ sudah tepat untuk menghasilkan susu kecipir dengan viskositas dan stabilitas yang baik.

Hasil pengukuran $\mathrm{pH}$ terhadap susu kecipir dengan sifat organoleptik terbaik dibandingkan dengan $\mathrm{pH}$ susu kedelai berdasarkan Standar Nasional Indonesia; di mana $\mathrm{pH}$ susu kecipir $(6,92 \pm 0,01)$ masih berada dalam kisaran $\mathrm{pH}$ untuk susu kedelai $(6,5-7,0)$ (SNI, 1995). pH 
yang sedikit asam hingga netral merupakan $\mathrm{pH}$ yang ideal untuk susu kedelai, minuman berbasis kedelai, serta susu kecipir; karena tidak akan mempengaruhi rasa produk. Untuk susu kedelai dan minuman berbasis kedelai, standar minimum total padatan yang ditentukan dalam SNI (1995) adalah 11,50\% (b/b). Persentase total padatan yang lebih tinggi menunjukkan suspensi yang lebih terkonsentrasi dan kental sehingga meningkatkan kestabilan produk (Setyani Medikasari dan Astuti, 2009). Hasil analisa terhadap total padatan susu kecipir sedikit lebih rendah dari standar $\mathrm{SNI}$; yaitu hanya sebesar $(10,29 \pm 0,04) \% \mathrm{~b} / \mathrm{b}$. Hal ini mungkin disebabkan oleh proporsi biji kecipir dan air yang cukup rendah (1:8) sehingga menghsilkan produk susu yang kurang terkonsentrasi.

Hasil analisa juga menunjukkan bahwa kandungan protein susu kecipir adalah $(1,58 \pm 0,02) \% \mathrm{~b} / \mathrm{b}$; lebih rendah dari SNI (1995) untuk kandungan minimal protein susu kedelai $(2,0 \% \mathrm{~b} / \mathrm{b})$; namun lebih tinggi daripada standar protein untuk minuman berbasis kedelai $(1,0 \%$ b/b). Selain itu, kandungan lemak dari sampel susu kecipir dengan formulasi terbaik adalah $(0,88 \pm 0,03) \% \mathrm{~b} / \mathrm{b}$; relatif lebih rendah jika dibandingkan dengan standar minimal SNI untuk kandungan lemak susu kedelai, yaitu $1,0 \% \mathrm{~b} / \mathrm{b}$ dan jauh lebih tinggi dari standar kadar lemak untuk minuman berbasis kedelai, yaitu sebesar $0,30 \% \mathrm{~b} / \mathrm{b}$ (SNI, 1995). Rendahnya kandungan total solid, protein, dan lemak pada susu kecipir mungkin disebabkan oleh proporsi biji kecipir yang rendah (1:8) serta banyaknya residu yang mungkin memiliki kandungan nutrisi yang tinggi namun terbuang akibat proses filtrasi.

Terkait dengan kandungan fenolik, flavonoid, dan aktivitas antioksidan, secara umum kandungan fenolik dan flavonoid berbanding lurus dengan aktivitas antioksidan. Namun, interaksi sinergis dan antagonis mungkin terjadi antar-flavonoid bila kapasitas antioksidan ekstrak diukur secara keseluruhan (Hidalgo et al., 2010). Hasil percobaan sesuai dengan tren yang diamati dalam studi sebelumnya; di mana kandungan total fenolik dan flavonoid yang rendah berkontribusi terhadap menurunnya aktivitas antioksidan pada sampel susu kecipir.

Total fenolik, flavonoid, dan kapasitas antioksidan susu susu kecipir yang dihasilkan secara umum lebih rendah jika dibandingkan dengan karakteristik antioksidan dari rimpang jahe dan biji kecipir tua. Selain itu, pasteurisasi $\left(80^{\circ} \mathrm{C}, 15\right.$ menit) yang diterapkan pada proses pembuatan susu kecipir berdampak pada penurunan total fenolik, flavonoid, serta aktivitas antioksidan dari produk susu yang dihasilkan. Irina dan Mohamed (2012) melaporkan bahwa hampir semua proses termal termasuk pengeringan, blansir, pasteurisasi, atau penggunaan microwave mengakibatkan degradasi pada fenolik dan senyawa flavonoid. Dalam studi yang dilakukan oleh Xu dan Chang (2008), total fenolik, flavonoid, tanin yang terkondensasi, serta \%SA dalam produk olahan kedelai secara signifikan lebih rendah $(a=0,05)$ dibandingkan dengan konten pada kedelai mentah.

Tidak ada standar khusus untuk yang menyatakan tinggi atau rendahnya kadar tannin dalam sumber makanan. Namun demikian, Villamor et al. (2009) mengklasifikasikan anggur berdasarkan kadar tannin; yaitu: $\leq 400 \mathrm{mg}$ EK / L ( $\leq 0,4 \mathrm{mg}$ EK / g sampel) untuk anggur dengan kadar tannin rendah dan $\geq 800 \mathrm{mg} E K / \mathrm{L}$ $(\geq 0,8 \mathrm{mg}$ EK / g sampel) untuk anggur berkadar tannin tinggi. Oleh karena itu, dapat disimpulkan bahwa kandungan tannin dalam sampel susu kecipir sangat rendah (Tabel 4). Proporsi biji kecipir yang rendah dalam formulasi; yaitu 1:8, menyebabkan efek yang ditimbulkan terhadap karakteristik rasa susu kecipir tidak signifikan.

\section{Komposisi Asam Amino}

Berdasarkan hasil analisa untuk komposisi asam amino, susu kecipir memiliki kandungan asam glutamate $(3.411,10 \mathrm{ppm})$, asam aspartat $(2.854,02 \mathrm{ppm})$, dan lisin $(2.475,93 \mathrm{ppm})$ yang tinggi. Meskipun demikian, konsentrasi triptofan $(159,52 \mathrm{ppm})$, metionin $(303,07$ $\mathrm{ppm}$ ), dan sistein sangat rendah sehingga mengurangi kualitas protein susu kecipir. Menurut Chimmad, et al. (1998), kandungan lisin yang melimpah; yaitu sebanyak $7,9 \mathrm{~g}$ per $100 \mathrm{~g}$ protein biji kecipir tua dan 2.475,93 ppm $(0,0192 \mathrm{~g} / 100 \mathrm{ml})$ dalam susu kecipir dapat menutupi kekurangan asam amino tersebut dalam beras, jagung, dan umbi-umbian. Namun, kandungan lisin dalam susu kecipir masih lebih rendah jika dibandingkan dengan susu kedelai yang diketahui sebanyak $0,3830 \mathrm{~g} / 100 \mathrm{ml}$. Terlepas dari fakta bahwa sistein dan metionin adalah asam amino pembatas dalam biji kecipir dan kacangkacangan lainnya, kandungan sistein tidak terdeteksi dalam sampel. Hal ini mungkin terjadi karena rendahnya proporsi biji kecipir yang digunakan dalam formulasi; sehingga tidak mewakili keberadaan sistein dalam susu.

\section{Senyawa Metabolit Sekunder}

Berdasarkan hasil analisis GC-MS, terdapat 18 puncak senyawa yang terintegrasi. Puncak nomor 8 dengan rasio $\mathrm{m} / \mathrm{z} 97$ memiliki kelimpahan relatif tertinggi; yaitu sebesar $219.313,1$ atau $30,33 \%$ dari total luas area dan diidentifikasi sebagai 2-furancarboxaldehyde 5(hydroxymethyl)- atau dikenal sebagai hydroxymethylfurfural (HMF). Adanya HMF mengindikasikan proses pemanasan yang berlebihan pada produk susu. Namun, menurut Henry dan Chapman (2002), HMF telah digunakan sebagai indikator proses pemasakan yang memadai pada produk susu. Selain itu, HMF merupakan produk intermediet dalam reaksi Maillard dan dihasilkan dari degradasi gula pada temperatur tinggi.

Produk makanan dan minuman berkadar air sedang dengan $\mathrm{pH}$ 4-7 dan suhu di atas $50^{\circ} \mathrm{C}$ serta mengandung protein dan karbohidrat tinggi sangat berpotensi mengalami reaksi Maillard (Jimenez et al., 2000). Susu kecipir memiliki karakteristik yang tepat 
untuk reaksi Maillard dan mengalami pasteurisasi pada suhu $80^{\circ} \mathrm{C}$ selama 15 menit. Oleh karena itu, terbentuknya seyawa baru bahkan pada jumlah yang sangat sedikit; mungkin terjadi akibat reaksi Maillard.

Terlepas dari deteksi HMF, analisa melalui GC-MS juga mendeteksi keberadaan sebuah senyawa volatil hasil reaksi sampingan Maillard yang mengandung kelompok dikarbonil; yang diidentifikasi sebagai oxalic acid, monoamide, n-propyl, undecyl ester dengan $18,7263 \%$ dari total luas area. Wojdylo et al. (2007) melaporkan bahwa Adanya kelompok dikarbonil mengindikasikan aktivitas antioksidan yang tinggi dalam suatu senyawa. Meskipun demikian, kandungan oxalic acid, monoamide, n-propyl, undecyl ester dalam sampel susu kecipir sangat sedikit, sehingga tidak berdampak besar pada aktivitas antioksidan.

\section{Kesimpulan dan Saran}

Kesimpulan

Kedua metode blansir; baik dengan uap maupun air panas tidak memiliki dampak yang signifikan terhadap tingkat penerimaan konsumen terhadap aroma, rasa, viskositas, dan penerimaan keseluruhan dari produk susu kecipir yang dihasilkan $(a=0,05)$; sehingga tidak ada perlakuan pendahuluan blansir yang diterapkan. Susu kecipir yang diproduksi dengan rasio 1:8 (biji kecipir tua : air) dan $0,01 \%$ kappa karagenan secara signifikan memiliki laju pengendapan yang paling rendah dan sifat organoleptik yang lebih disukai konsumer; berkaitan dengan parameter rasa, viskositas, serta penerimaan keseluruhan $(a=0,05)$. Formulasi susu kecipir dengan rasio 1:8 (biji kecipir tua : air), 0,01\% kappa karagenan, dan penambahan $12,27 \%$ jus jahe kuning ( $/ / v)$ secara signifikan meningkatkan akseptabilitas konsumer terhadap susu kecipir. Nilai hedonis yang diberikan untuk parameter warna, aroma, rasa, viskositas dan penerimaan keseluruhan masing-masing adalah 5,41; 4,$67 ; 4,96 ; 4,81 ;$ dan 5,04 . Selain itu, susu kecipir dengan sifat organoleptik terbaik memiliki nilai kecerahan warna 52,75; viskositas $16,18 \mathrm{mPa} . \mathrm{s}$; $\mathrm{pH} 6,92$; kandungan total fenol 0,27 mg EAG / g sampel; kandungan flavonoid 0,24 mg EK / g sampel; kapasitas antioksidan sebesar 14,53 mg EVC / L sampel $(26,62 \%$ SA); dan kandungan tanin sebesar $0,24 \mathrm{mg}$ EK / $\mathrm{g}$ sampel. Kandungan total padatan, protein, dan lemak dalam susu kecipir; yaitu masing-masing sebesar $10,29 \%, 1,58 \%$, dan $0,88 \%$ membuat produk ini memenuhi standar dan dapat disetarakan dengan produk minuman berbasis kedelai lainnya; namun kandungan nutrisinya masih lebih rendah daripada susu kedelai.

\section{Saran}

Pembuatan susu kecipir dengan adisi jus jahe emprit dan bahan penstabil kappa karagenan dapat diimplementasikan dalam skala industri. Hal ini didukung dengan ketersediaan bahan baku yang dapat diperoleh sepanjang tahun serta proses produksi yang membutuhkan biaya rendah dan waktu yang singkat. Penggunaan jus jahe emprit sebagai bahan aditif alami dapat mengurangi intensitas bau langu sehingga meningkatkan akseptabilitas konsumen terhadap susu kecipir. Selain itu, kappa karagenan sebagai bahan penstabil juga memperbaiki stabilitas produk tanpa mempengaruhi karakteristik organoleptiknya.

\section{Ucapan Terimakasih}

Penulis mengucapkan terimaksih kepada PT Indofood CBP Sukses Makmur Tbk., melalui program Indofood Riset Nugraha periode 2014/2015 atas bantuan finansial yang telah diberikan untuk merampungkan penelitian ini.

\section{Daftar Pustaka}

AOAC. 2005. Official Method of Analysis: The Association of Official Analytical Chemist (18 ed.). AOAC, Inc., Virginia.

Astawan M. 2009. Sehat dengan Kacang dan Biji-bijian. Penebar Swadaya, Cimanggis.

Aziadekey M. 2001. Effects of soybean cultivas on soymilk quality. Tropicultura 19(4): 203-205.

Chimmad B, Rao M, Srinivasan C, Megeri S. 1998. Protein quality of winged bean seeds. Karnataka J. Agric. Sci. 11(3): 770-774.

Ekade PP, Manik SR. 2014. Determination of phytoconstituents of dolichandrone falcata seem flower through GC-MS. International Journal for Pharmaceutical Research Scholars (IJPRS) 3(1): 573-580.

Ghafoor K, Al-Juhaimi F, Park J. 2011. High pressure treatments of soybean and soybean products. Recent Trends for Enhancing the Diversity and Quality of Soybean Products: 67-80.

Haryoto. 1998. Teknologi Tepat Guna Tempe \& Kecap Kecipir. Kanisius, Jakarta.

Henry C, Chapman C. 2002. The Nutrition Handbook for Food Processors. CRC Press LLC, Boca Raton, Florida.

Hidalgo M, Sanchez-Moreno C, de Pascual-Teresa S. 2010. Flavonoid-flavonoid interaction and its effect on their antioxidant activity. Food Chemistry 121: 691-696. doi:10.1016/j.foodchem.2009.12.097.

Irina I, Mohamed G. 2012. Biologival activities and effects of food processing on flavonoids as phenolic antioxidants. Advances in Applied Biotechnology.101-124. DOI: 10.5772/30690.

Jimenez A, Villanova B, Hernandez E. 2000. Hydroxymethylfurfural and methylfurfural ccontent of selected bakery products. Food Research International 3: 833-838.

Kantha SS, Erdman JW. 1984. The winged bean as an oil and protein source: A review. JAOCS 61(3): 515525. DOI: 10.1007/BF02677021.

Kneifel W, Ulberth F, Scchaffer E. 1992. Tristimulus color reflectance measurement of milk and dairy 
products. Lait 72: 389-391. DOI: 10.1051/lait:1992427.

Krisnawati A. 2010. Keragaman genetik dan potensi pengembangan kecipir (Psophocarpus tetragonolobus L.) di Indonesia. Jurnal Litbang Pertanian 29(3): 113-119.

Lawless HT. 2013. Quantitative Sensory Analysis: Psychophyics, Models and Intelligent Design. John Wiley \& Sons, Ltd., Chichester.

Liu Z, Chang SK. 2007. Soymilk viscosity as influenced by heating methods and soybean varieties. Journal of Food Processing and Preservation 31: 320-333. DOI: 10.1111/j.1745-4549.2007.00128.x.

Ludvigsen H. 2011. Manufacturing Delicious Soy Milk. Palsgaard, Copenhagen.

Lv Y, Li H, Wu X, Guo S. 2011. Grinding process with hot water on beany and non-beany flavor in soymilk. Journal of Food Science 76(1): 520-525. DOI: 10.1111/j.1750-3841.2010.01947.x.

Miyamoto T, Matsushima F, Nakae T. 1986. Yogurt-like fermented bean milk prepeared by lactic acid bacteria from tropical vegetation. Jpn. J. Zootech. Sci 57(5): 411-429.

Monakhova Y, Godelmann R, Andlauer C, Kuballa T, Lachenmeler D. 2013. Identification of imitation cheese and imitation ice cream based on vegetable fat using $\mathrm{nmr}$ spectroscopy and chemometrics. International Journal of Food Science 2013: 1-9.

Mtebe K, Gordon M. 1987. Volatiles derived from lipoxygenase-catalysed reactions in winged beans (Psophocarpus tetragonolobus). Food Chemistry 23: 175-182. DOI: 10.1016/0308-8146(87)90137-3.

Nurhadi N. Analisis Situasi Perkedelaian Nasional. Balai Besar Penelitian Pertanian [Internet]. 2012 Mar [cited 2013 Nov 21]. Available from: http://bbppketindan.bppsdmp.deptan.go.id/arsip/arti kel/artikel-pertanian

Nollet LM. 1996. Handbook of Food Analysis: Physical Characterization and Nutrient Analysis. Marcel Dekker, Inc., New York.

Pakrashi S, Pakrashi A. 2003. Ginger: A Versatile Healing Herb. New Delhi: Vedams ebooks. Pvt. Ltd., Delhi.

Phillips G, Williams P. 2009. Handbook of Hydrocolloids (2nd ed.). CRC Press LLC, Boca Raton, Florida.

Prescott J, Norris L, Kunst M, Kim S. 2005. Estimating a "Consumer Rejection Threshold" for cork taint in white wine. Food Quality and Preference 15: 345349. doi:10.1016/j.foodqual.2004.05.010.

Rorong J, Suryanto E. 2010, May. Analisis fitokimia enceng gondok (Eichhornia crassipes) dan efeknya sebagai agen photoreduksi $\mathrm{Fe}_{3}{ }^{+}$. Chem. Prog. 3(1): 33-41.

Rostiana O, Abdullah A, Taryono, Hadad E. 1991. Jenisjenis tanaman jahe. Littro VII(1): 7-10.

SNI. 1992. Cara Uji Makanan dan Minuman. Jakarta: Badan Standardisasi Nasional.
SNI. 1995. Susu Kedelai. Jakarta: Badan Standardisasi Nasional.

Salunkhe DK, Chavan JK, Adsule RN, Kadam SS. 1992. Oilseeds: Chemistry, Technology and Utilization. Van Nostrand Reinhold, New York.

Setyani S, Medikasari, Astuti WI. 2009. Fortifikasi jagung manis dan kacang hijau terhadap sifat fisik, kimia dan organoleptik susu jagung manis kacang hijau. Jurnal Teknologi Kimia dan Industri 3(1): 438-445.

Sowonola OA, Tunde-Akintunde TY, Adedeji F. 2005. Nutritional and sensory qualities of soymilk-kunnu blends. African Journal of Food and Nutritional Sciences 5(2):1-12.

Sualang O. 2006. Pengaruh aplikasi kappa karagenan terhadap stabilitas susu kedelai (Glycine max, L. MER). Jurnal Litbang Pertanian 5(6): 125-131.

Sugkhaphan P, Kijroongrojana K. 2009. Optimization of prebiotics in soybean milk using mixture experiments. Songklanakarin Journal of Science and Technology 31(5): 481-490.

Sun DW. 2012. Handbook of Frozen Food Processing and Packaging. CRC Press, Boca Raton, Florida.

Tangkanakul $\mathrm{P}$, Auttaviboonkul $\mathrm{P}$, Niyomwit B, Lowvitoon N, Charoenthamawat $P$, Trakoontivakorm G. 2009. Antioxidant capacity, total phenolic content and nutritional composition of asian foods after thermal processing. International Food Research Journal 16: $571-580$.

Van de Velde F, De Ruiter GA. 2005. Carrageenan (Vol. $\mathrm{VI})$. Wiley-VCH, Winham.

Villamor RR, Harbertson JF, Ross CF. 2009. Influence of tannin concentration, storage temperature, and time on chemical and sensory properties of cabernet sauvignon and merlot wines. Am. J. Enol. Vitic. 60(4): 442-449.

Wojdylo A, Oszmianski J, Czemerys R. 2007. Antioxidant activity and phenolic compounds in 32 selected herbs. Food Chemsitry: 940-949. doi:10.1016/j.foodchem.2007.04.038.

Wrolstad R, Acree T, Decker E, Penner M, Reid D, Schwartz S, et al. 2005. Handbook of Food Analytical Chemistry: Pigments, Colorants, Flavors, Texture and Bioactive Food Components (2nd ed.). John Wiley \& Sons, Inc., Hoboken.

Xu B, Chang SK. 2008. Total phenolics, phenolic acids, isoflavones, and anthocyanins and antioxidant properties of yellow and black soybeans as affected by thermal processing. J. Agric. Food Chem. 56(16): 7165-7175. DOI: $10.1021 / \mathrm{jf} 8012234$.

Yang M, Li L. 2010. Physicochemical, textural and sensory characteristics of probiotic soy yogurt prepared from germinated soybean. Food Technol. Biotechnol. 48(4): 490-496. 